\title{
PEMANFAATAN STEEL SLAG INDONESIA DI BIDANG PERTANIAN
}

\section{Utilization of Indonesian Steel Slag in Agriculture}

\author{
Suwarno \\ Departemen Ilmu Tanah dan Sumberdaya Lahan, Fakultas Pertanian \\ Institut Pertanian Bogor Jl. Meranti, Kampus IPB Darmaga, Bogor 16680 \\ Telp.: (0251) 8629360, HP: 08128701261 \\ Email: suwarno_ipb@yahoo.com
}

\begin{abstract}
Steel slag is by-product formed in the process of steel manufacturing. In Europe, USA, Japan, China, Korea, and Hawai steel slag has been utilized in agriculture as a liming material for improving acid soil or as Si source for paddy rice and sugar cane plants. Currently, Indonesia produces annually about 540,000 ton of electric furnace (EF) - one kind of steel slag; however none of this is being used in agriculture. Results of researches indicated that Indonesian steel slag could be utilized as a liming material, Si source, as well as peat soil amendment. As a liming material, effect of Indonesian steel slag on growth of plant was slightly better than those of calcite and dolomite. In combination with phosphatic guano, Indonesian steel slag increased effectiveness of phosphatic guano for direct application as P fertilizer. Phosphatic guano was significantly more effective when it was combined with steel slag than be combined with dolomite or calcite. As Si source for paddy rice plant, Indonesian steel slag improved growth and yield of paddy rice both grown on mineral soil containing low available Si on peat soil. The effect of Indonesian steel slag on paddy rice grown on peat soil was significantly better than that of on mineral soil. As peat soil amendment, Indonesian steel slag enhanced growth and bole volume of Acacia cracicarpa grown on peat soil.
\end{abstract}

Keywords: agriculture, Indonesian steel slag, utilization

\section{PENDAHULUAN}

Steel slag (terak baja) adalah produk sampingan yang terbentuk dalam proses pembuatan baja. Secara garis besar, proses pembuatan baja dibagi menjadi tiga proses, yaitu: proses pembuatan besi, proses pembuatan baja, dan proses pemberian bentuk produk (Umegaki, 1986; Anon., 1994). Berdasarkan proses tersebut, steel slag dikelompokkan atas blast furnace slag (BF slag) dan slag pembuatan baja (steel-making slag) (Washimi, 1986; Anon, 1996). Karena BF slag diproduksi dalam proses pembuatan besi, maka slag ini disebut juga slag pembuatan besi. Proses pembuatan baja dilaksanakan dengan metode open hearth furnace, converter (basic oxygen furnace), atau electric furnace (Nishiwaki, 1986). Berdasarkan metode tersebut, slag pembuatan baja diklasifikasikan atas: open hearth slag (OH slag), converter slag (C slag), dan electric furnace slag (EF slag) (Washimi, 1986).

Steel slag merupakan material yang bermanfaat di bidang pertanian, karena steel slag dapat digunakan sebagai bahan pengapuran untuk memperbaiki kondisi tanah masam (Crane, 1930; Naftel; 1937; Carter et al., 1951; Suwarno dan Goto, 1997a) maupun sebagai pupuk Si untuk tanaman padi sawah maupun tebu (Ota et al., 1955; Ayres, 1966; Suwarno and Goto, 1997b; Ma dan Takahashi, 2002). Di Jerman material ini sudah digunakan sebagai bahan pengapuran sejak tahun 1937, dan di Amerika Serikat sudah digunakan sejak tahun 1939 (Ma dan Takahashi, 2002).
Di Jepang pada awalnya steel slag juga digunakan sebagai bahan pengapuran, seperti halnya di Jerman dan di Amerika Serikat. Namun, karena manfaatnya untuk tanaman padi sawah telah terbukti, maka pada tahun 1955 steel slag ditetapkan sebagai pupuk Si oleh Kementerian Pertanian, Kehutanan, dan Perikanan (Ma dan Takahashi, 2002). Jenis steel slag yang umum digunakan sebagai pupuk Si adalah $B F$ slag dan sering dikenal dengan sebutan calcium silicate slag. Di Cina dan Korea steel slag juga telah dimanfaatkan sebagai pupuk Si untuk tanaman padi sawah (De Datta, 1981).

Di Hawai, adanya respons hasil yang sangat nyata tanaman tebu dan tanaman lain terhadap pemberian calcium silicate slag pada tanah dengan tingkat pelapukan lanjut menyebabkan steel slag digunakan secara komersiil sebagai pupuk Si oleh perkebunan tebu. Hasil penelitian juga menunjukkan bahwa EF slag dapat meningkatkan produksi tebu seperti halnya dengan BF slag (Ayres, 1966; Fox et al., 1967).

Jenis steel slag yang dihasilkan Indonesia adalah $E F$ slag. Total produksi jenis slag ini mencapai 540,000 ton tahun $^{-1}$, yaitu 240,000 ton diproduksi oleh PT Krakatau Steel dan sisanya (300,000 ton) diproduksi oleh pabrikpabrik lain, seperti PT. Gunung Garuda, PT. Ispatindo, dan PT. Master steel. Sampai saat ini slag tersebut belum ada yang dimanfaatkan di bidang pertanian. Bahan tersebut hanya dimanfaatkan untuk urug jalan, urug rawa, urug tempat parkir, pengganti bahan baku pembuatan semen, 
serta pembersih kapal, tangki penimbun minyak, dan lainlain. Hasil-hasil penelitian menunjukkan bahwa EF slag Indonesia dapat digunakan sebagai bahan pengapuran untuk memperbaiki kondisi tanah masam (Suwarno dan Goto, 1997a; Suwarno, 1999), bermanfaat sebagai pupuk Si untuk tanaman padi sawah (Suwarno dan Goto, 1997b; Suwarno, 2002), serta dapat dimanfaatkan sebagai bahan pembenah tanah gambut.

\section{HASIL PENELITIAN PEMANFAATAN EF SLAG INDONESIA DI BIDANG PERTANIAN}

\section{Penggunaan EF Slag Indonesia sebagai Bahan Pengapuran}

Percobaan pot dilaksanakan untuk mengevaluasi $E F$ slag Indonesia sebagai bahan pengapuran pada Andisol untuk tanaman komatsuna (Brassica chinensis L.) serta membandingkannya dengan $C$ slag Jepang dan dolomit. Ketiga bahan pengapuran tersebut diberikan dalam dua dosis, yaitu: dosis 1 (untuk mencapai pH 6.5) dan dosis 2 (2 kali dosis 1).

Tabel 1. Pengaruh EF Slag Indonesia, C Slag Jepang, dan dolomit terhadap pertumbuhan dan kadar hara Komatsuna serta ketersediaan hara dalam tanah

\begin{tabular}{|c|c|c|c|c|c|c|c|}
\hline \multirow[t]{2}{*}{ Perlakuan } & \multirow[t]{2}{*}{ BK Tajuk } & \multicolumn{3}{|c|}{$\begin{array}{c}\text { Kadar Hara } \\
\text { Tanaman }\end{array}$} & \multicolumn{3}{|c|}{ Kadar Hara Tanah } \\
\hline & & $\mathrm{Fe}$ & $\mathrm{Mn}$ & B & $\begin{array}{c}\mathrm{Fe} \\
\text { Ters } \\
(\mathrm{ppm}) .\end{array}$ & $\begin{array}{l}\text { Mn } \\
\text { Ters }\end{array}$ & $\begin{array}{c}\text { B } \\
\text { Ters }\end{array}$ \\
\hline Kontrol & $2.04 \mathrm{ab}$ & 261 & 381 & 21.1 & 16.6 & 4.41 & 0.23 \\
\hline Dolomit 1 & $3.76 \mathrm{~cd}$ & 144 & 162 & 7.2 & 18.9 & 1.99 & 0.09 \\
\hline Dolomit 2 & $0.62 \mathrm{a}$ & 188 & 50 & 4.4 & 18.5 & 0.59 & 0.05 \\
\hline EF Slag 1 & $6.21 \mathrm{e}$ & 122 & 220 & 21.6 & 36.1 & 6.55 & 0.26 \\
\hline EF Slag 2 & $5.04 \mathrm{de}$ & 121 & 223 & 22.0 & 54.3 & 12.1 & 0.28 \\
\hline C Slag 1 & $5.01 \mathrm{de}$ & 111 & 381 & 23.9 & 37.8 & 20.2 & 0.30 \\
\hline C Slag 2 & $4.86 \mathrm{de}$ & 110 & 293 & 21.9 & 47.4 & 22.8 & 0.30 \\
\hline
\end{tabular}

Angka yang diikuti oleh huruf yang sama tidak berbeda nyata menurut Uji HSD taraf $\alpha=5 \%$

Dari hasil percobaan tersebut (Tabel 1) diketahui bahwa EF slag Indonesia secara nyata memperbaiki pertumbuhan dan produksi komatsuna. Produksi komatsuna yang diberi $E F$ slag Indonesia tidak berbeda nyata dengan yang diberi $C$ slag Jepang. Selain itu, pengaruh $E F$ slag Indonesia dan $C$ slag Jepang pada tanaman tersebut lebih baik daripada dolomit karena keduanya pada dosis tinggi (dosis 2) tidak menimbulkan defisiensi B dan Mn. Hasil analisis tanah dan tanaman menunjukkan bahwa pemberian dolomit pada dosis tinggi menurunkan ketersediaan B dan Mn dalam tanah serta kadar B dan Mn dalam tanaman komatsuna. Hal ini menyebabkan terjadinya defisiensi B dan Mn pada tanaman tesebut (Suwarno and Goto, 1997a).

Percobaan pot lanjutan dilakukan untuk mengevaluasi EF slag Indonesia sebagai bahan pengapuran pada Ultisol untuk tanaman kedelai (Glycine max L. Merr.) (sebagai tanaman pertama) dan sorghum (Sorghum vulgare Pers.) (sebagai tanaman kedua) serta membandingkannya dengan kalsit. Kedua bahan pengapuran diberikan dalam tiga taraf, yaitu untuk mencapai pH 5.5, 6.0, dan 6.5.

Tabel 2. Pengaruh EF Slag Indonesia dan kalsit terhadap pertumbuhan dan produksi kedelai (sebagai tanaman pertama) dan sorghum sebagai tanaman kedua

\begin{tabular}{lcccc}
\hline \multirow{2}{*}{ Perlakuan } & \multicolumn{2}{c}{ Kedelai } & & $\begin{array}{c}\text { Sorghum } \\
\text { (Tanaman Pertama })\end{array}$ \\
\cline { 2 - 3 } & $\begin{array}{c}\text { Bobot Kering } \\
\text { biji } \\
\left(\mathrm{g} \mathrm{pot}^{-1}\right)\end{array}$ & $\begin{array}{c}\text { Prod } \\
\text { Relatif } \\
(\%)\end{array}$ & & $\begin{array}{c}\text { Bobot Basah } \\
\text { Tajuk } \\
\left(\mathrm{g} \mathrm{pot}^{-1}\right)\end{array}$ \\
\hline & & & \\
Kontrol & $5.84 \mathrm{a}$ & $100 \mathrm{a}$ & & $0.6 \mathrm{a}$ \\
Kalsit pH 5.5 & $7.34 \mathrm{ab}$ & $126 \mathrm{ab}$ & & $0.6 \mathrm{a}$ \\
Kalsit pH 6.0 & $10.0 \mathrm{ab}$ & $171 \mathrm{ab}$ & & $478.4 \mathrm{~b}$ \\
Kalsit pH 6.5 & $4.64 \mathrm{a}$ & $79 \mathrm{a}$ & & $695.2 \mathrm{c}$ \\
EF Slag pH 5.5 & $5.86 \mathrm{a}$ & $100 \mathrm{a}$ & & $0.8 \mathrm{a}$ \\
EF Slag pH 6.0 & $13.4 \mathrm{~b}$ & $229 \mathrm{~b}$ & & $731.8 \mathrm{c}$ \\
EF Slag pH 6.5 & $10.1 \mathrm{ab}$ & $172 \mathrm{ab}$ & & $809.7 \mathrm{c}$ \\
\hline
\end{tabular}

Angka yang diikuti oleh huruf yang sama pada kolom yang sama tidak berbeda nyata menurut Uji HSD taraf $\alpha=5 \%$

Hasil percobaan yang disajikan pada Tabel 2 menunjukkan bahwa pengaruh EF slag Indonesia terhadap produksi kedelai cenderung lebih baik daripada kalsit. Selanjutnya, pada tanaman kedua, pengaruh residu EF slag terhadap pertumbuhan tanaman sorghum juga cenderung lebih baik daripada kalsit (Suwarno, 1999).

Percobaan pot lain dilakukan untuk mengevaluasi penggunaan guano fosfat sebagai pupuk $\mathrm{P}$ secara langsung yang dikombinasikan dengan EF slag Indonesia dan dolomit untuk tanaman komatsuna pada Andisol. Kedua kombinasi juga dibandingkan dengan pupuk Fused Magnesium Fosfat (FMP) dan Super Fosfat (SP) yang dikombinasikan dengan dolomit. Guano fosfat, FMP, dan SP diberikan dalam dua taraf, $5 \%$ dan $10 \%$ koefisien jerapan fosfat, sedangkan EF slag dan dolomit diberikan dalam satu taraf untuk mencapai $\mathrm{pH}$ 6.5. 


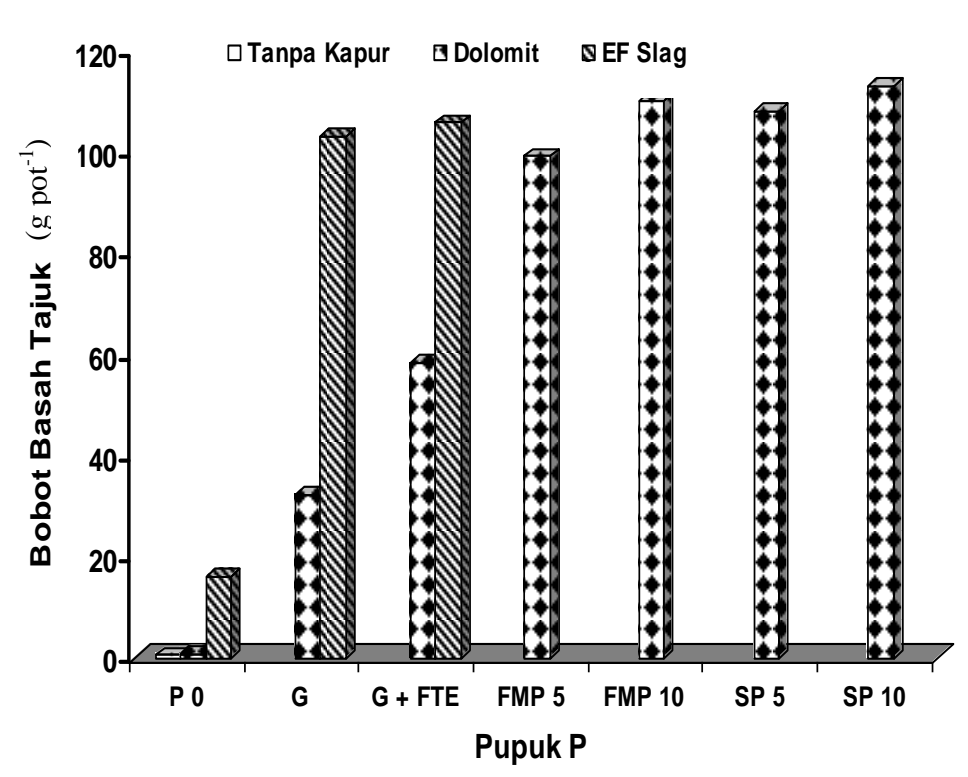

Gambar 1. Pengaruh kombinasi bahan pengapuran dengan pupuk $\mathrm{P}$ terhadap pertumbuhan Komatsuna

Dari hasil percobaan tersebut (Gambar 1) diketahui bahwa guano fosfat jauh lebih efektif bila dikombinasikan dengan EF slag Indonesia daripada dikombinasikan dengan dolomit. Produksi komatsuna pada perlakuan kombinasi guano fosfat dengan EF slag tidak berbeda nyata dengan perlakuan kombinasi dolomit dengan pupuk FMP maupun SP. Penambahan pupuk mikro FTE (fritted trace element) yang berisi Mn dan B pada kombinasi guano fosfat dengan dolomit nyata meningkatkan pertumbuhan dan produksi komatsuna, namun penambahan FTE pada kombinasi guano fosfat dengan $\mathrm{EF}$ slag tidak memperbaiki pertumbuhan dan produksi tanaman tersebut (Suwarno dan Goto, 2002).

Percobaan pot selanjutnya dilaksanakan untuk membandingkan pengaruh kombinasi guano fosfat dengan EF slag dan guno fosfat dengan kalsit pada tanaman sorghum yang ditanam pada Ultisol. Tiap pot diisi dengan tanah setara dengan $5 \mathrm{~kg}$ berat kering oven. Guano fosfat diberikan dalam empat taraf, yaitu: 0, 100, 200, dan 300 $\mathrm{mg} / \mathrm{kg}$, sedangkan dolomit dan EF slag diberikan dalam dua taraf, yaitu tanpa (kontrol) dan 2 X Al dd.

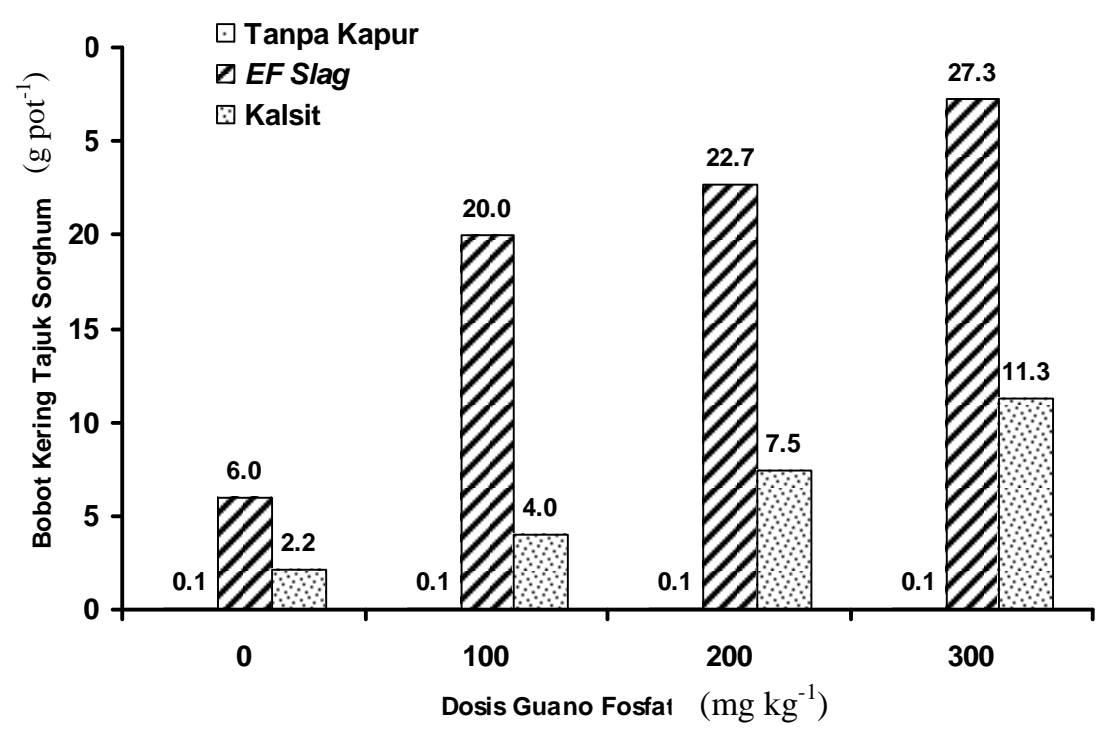

Gambar 2. Pengaruh kombinasi Guano Fosfat dengan EF Slag dan Guano Fosfat dengan kalsit terhadap pertumbuhan sorghum

Hasil percobaan yang tertera pada Gambar 2 menunjukkan bahwa baik EF slag maupun kalsit secara nyata meningkatkan efektivitas guano fosfat. Guano fosfat nyata lebih efektif bila dikombinasi dengan EF slag Indonesia daripada bila dikombinasikan dengan kalsit (Suwarno et al., 2003). 


\section{Penggunaan EF Slag Indonesia sebagai Pupuk Si pada} Tanaman Padi Sawah

Percobaan pot dilakukan untuk mengevaluasi penggunaan EF slag Indonesia sebagai pupuk Si untuk tanaman padi sawah (Oryza sativa L. varietas Koshihikari yang ditanam pada tanah jenis Regosol (ordo Entisol) serta membandingkannya dengan $C$ slag Jepang, PTC slag, dan $B F$ slag Jepang. Tiap pot diisi dengan tanah setara dengan $3 \mathrm{~kg}$ berat kering oven dan ketiga jenis slag diberikan dalam dua taraf, yaitu 10 dan $20 \mathrm{~g} \mathrm{pot}^{-1}$ (setara dengan 3.33 dan $6.66 \mathrm{~g} \mathrm{~kg}^{-1}$ ).

Tabel 3. Pengaruh berbagai jenis Slag terhadap produksi padi sawah varietas Koshihikari pada Regosol

\begin{tabular}{lcc}
\hline \multirow{2}{*}{ Perlakuan } & \multicolumn{2}{c}{ Produksi Gabah Bernas } \\
\cline { 2 - 3 } & $\begin{array}{c}\text { Aktual } \\
\left(\mathrm{g} \mathrm{pot}^{-1}\right)\end{array}$ & $\begin{array}{c}\text { Relatif } \\
(\%)\end{array}$ \\
\hline Kontrol & $18.7 \mathrm{a}$ & $100 \mathrm{a}$ \\
EF Slag 10 & $23.2 \mathrm{ab}$ & $124 \mathrm{ab}$ \\
EF Slag 20 & $25.4 \mathrm{~b}$ & $136 \mathrm{~b}$ \\
BF Slag-1 10 & $20.7 \mathrm{ab}$ & $111 \mathrm{ab}$ \\
BF Slag-1 20 & $21.2 \mathrm{ab}$ & $114 \mathrm{ab}$ \\
BF Slag-2 10 & $20.5 \mathrm{ab}$ & $110 \mathrm{ab}$ \\
BF Slag-2 20 & $20.6 \mathrm{ab}$ & $110 \mathrm{ab}$ \\
FC Slag 10 & $19.9 \mathrm{ab}$ & $106 \mathrm{ab}$ \\
FC Slag 20 & $21.8 \mathrm{ab}$ & $117 \mathrm{ab}$ \\
\hline
\end{tabular}

\begin{tabular}{lcc}
\hline \multirow{2}{*}{ Perlakuan } & \multicolumn{2}{c}{ Produksi Gabah Bernas } \\
\cline { 2 - 3 } & $\begin{array}{c}\text { Aktual } \\
\left(\mathrm{g} \mathrm{pot}^{-1}\right)\end{array}$ & $\begin{array}{c}\text { Relatif } \\
(\%)\end{array}$ \\
\hline CC Slag 10 & $20.2 \mathrm{ab}$ & $108 \mathrm{ab}$ \\
CC Slag 20 & $22.6 \mathrm{ab}$ & $121 \mathrm{ab}$ \\
PTC Slag 10 & $23.5 \mathrm{ab}$ & $126 \mathrm{ab}$ \\
PTC Slag 20 & $24.3 \mathrm{ab}$ & $130 \mathrm{ab}$ \\
\hline
\end{tabular}

Angka yang diikuti oleh huruf yang sama pada kolom yang sama tidak berbeda nyata menurut DMRT pada taraf $\alpha=5 \%$

Hasil percobaan (Tabel 3) menunjukkan bahwa pada tanah jenis Regosol yang berkadar Si tersedia rendah (134 $\mathrm{mg} \mathrm{kg}^{-1}$ ) EF slag, $C$ slag, dan $B F$ slag dapat meningkatkan produksi gabah bernas. Produksi gabah bernas kering giling dengan perlakuan $E F$ slag Indonesia cenderung lebih tinggi daripada dengan perlakuan $C$ slag Jepang maupun BF slag Jepang (Suwarno dan Goto, 1997c).

Percobaan pot lanjutan dilaksanakan untuk mengevaluasi penggunaan EF slag Indonesia sebagai pupuk Si untuk tanaman padi sawah varietas IR 64 yang ditanam pada tanah gambut. Tiap pot diisi dengan tanah gambut setara dengan $2 \mathrm{~kg}$ bobot kering oven. EF slag diberikan dalam tiga dosis, yaitu: $0,2.5$, dan $5 \%$ dari bobot kering tanah dan dikombinasikan dengan tiga jenis pupuk, yaitu pupuk majemuk NPK, Saprodap, dan pupuk standar (urea, SP 36, dan $\mathrm{KCl}$ ).

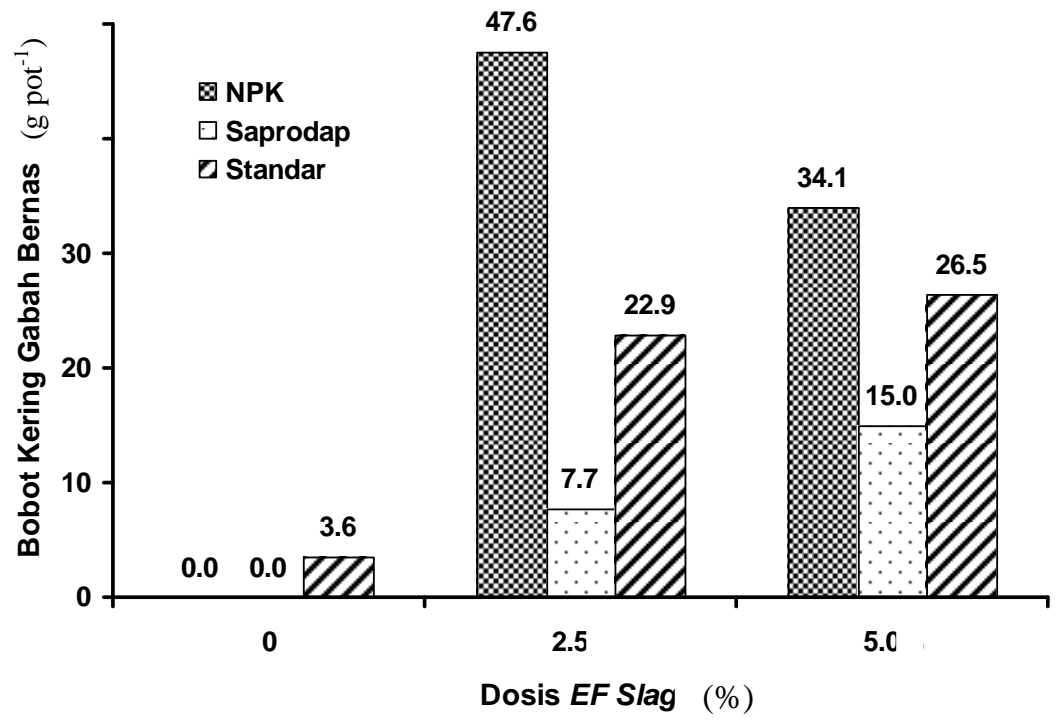

Gambar 3. Pengaruh EF slag dan beberapa jenis pupuk terhadap produksi padi sawah varietas IR 64 pada tanah Gambut

Hasil percobaan pada Gambar 3 menunjukkan bahwa pertumbuhan dan produksi padi sawah meningkat pesat dengan pemberian EF slag Indonesia. Pengaruh interaksi $E F$ slag dengan ketiga jenis pupuk juga bersifat nyata. Dari hasil analisis tanah (Tabel 4) diketahui bahwa pemberian EF slag Indonesia pada tanah gambut secara nyata meningkatkan ketersediaan $\mathrm{Si}, \mathrm{Ca}, \mathrm{Mg}$, serta meningkatkan $\mathrm{pH}$ tanah, tetapi menurunkan ketersediaan $\mathrm{Fe}, \mathrm{Cu}$, dan Zn (Suwarno, 2002). 
Tabel 4. Pengaruh EF Slag terhadap $\mathrm{pH}$ dan ketersediaan hara tanah Gambut dari Dendang, Jambi

\begin{tabular}{|c|c|c|c|c|c|c|c|c|}
\hline Perlakuan & $\mathrm{pH} \mathrm{H}_{2} \mathrm{O}$ & Ca Ters & Mg Ters & Si Ters & Fe Ters & Mn Ters & $\mathrm{Cu}$ Ters & Zn Ters \\
\hline \multicolumn{9}{|c|}{$\ldots \ldots\left(\right.$ me $\left.100 \mathrm{~g}^{-1}\right) \ldots \ldots \ldots$} \\
\hline $0 \%$ EF Slag & $3.8 \mathrm{a}$ & $1.17 \mathrm{a}$ & $1.15 \mathrm{a}$ & $71 \mathrm{a}$ & $14.5 \mathrm{c}$ & $1.03 \mathrm{a}$ & 1.39 & 1.88 \\
\hline $2.5 \%$ EF Slag & $5.3 \mathrm{~b}$ & $5.31 \mathrm{ab}$ & $5.20 \mathrm{a}$ & $224 \mathrm{ab}$ & $6.99 \mathrm{~b}$ & $6.44 \mathrm{c}$ & 1.11 & 1.61 \\
\hline $5.0 \%$ EF Slag & $6.2 \mathrm{c}$ & $9.04 \mathrm{~b}$ & $11.7 \mathrm{~b}$ & $582 \mathrm{~b}$ & $2.65 \mathrm{a}$ & $4.41 \mathrm{~b}$ & 0.96 & 0.65 \\
\hline
\end{tabular}

Angka yang diikuti oleh huruf yang sama pada kolom yang sama tidak berbeda nyata menurut Uji HSD taraf $\alpha=5 \%$

Percobaan lanjutan tentang penggunaan EF slag sebagai pupuk Si untuk tanaman padi sawah varietas IR 64 pada tanah gambut dilakukan di lapangan bertempat di Desa Trimulya, Kecamatan Mukok, Kabupaten Sanggau. EF slag diberikan dalam 5 taraf, yaitu: 0, 2.5, 5, 7.5, dan 10 ton $\mathrm{ha}^{-1}$.

Tabel 5. Pengaruh EF Slag terhadap produksi padi sawah varietas IR 64 pada tanah Gambut di Mukok, Sanggau

\begin{tabular}{ccc}
\hline \multirow{2}{*}{$\begin{array}{c}\text { Dosis EF Slag } \\
\left(\text { ton ha }^{-1}\right)\end{array}$} & \multicolumn{2}{c}{ Produksi Gabah Bernas } \\
\cline { 2 - 3 } & $\begin{array}{c}\text { Aktual } \\
\left(\text { ton ha }^{-1}\right)\end{array}$ & $\begin{array}{c}\text { Relatif } \\
(\%)\end{array}$ \\
\hline 0 & $2.43 \mathrm{a}$ & $100 \mathrm{a}$ \\
2.5 & $4.02 \mathrm{~b}$ & $165 \mathrm{~b}$ \\
5.0 & $4.50 \mathrm{bc}$ & $185 \mathrm{bc}$ \\
7.5 & $4.53 \mathrm{bcd}$ & $186 \mathrm{bcd}$ \\
10.0 & $4.77 \mathrm{~cd}$ & $196 \mathrm{~cd}$ \\
\hline
\end{tabular}

Angka yang diikuti oleh huruf yang sama pada kolom yang sama tidak berbeda nyata menurut Uji HSD taraf $\alpha=5 \%$
Hasil penelitian yang disajikan pada Tabel 5 menunjukkan bahwa pemberian EF slag Indonesia pada tanah gambut dengan dosis 2.5 - 10 ton ha ${ }^{-1}$ dapat meningkatkan produksi (gabah bernas kering giling) padi sawah IR 64 sebesar 1.59 - 2.34 ton ha $^{-1}(65-96 \%)$ (Suwarno dan Hidayatuloh, 2006, tidak dipublikasikan).

\section{Penggunaan EF Slag Indonesia sebagai Bahan Pembenah Tanah Gambut}

Percobaan lapangan dilaksanakan di hutan tanaman industri (HTI) PT Arara Abadi di Distrik Siak untuk mengevaluasi penggunaan EF slag Indonesia sebagai bahan pembenah tanah gambut yang ditanami Acacia cracicarpa serta membandingkannya dengan boiler ash. EF slag dan boiler ash diberikan dalam 5 taraf, yaitu: 0, 250, 500, 1000, dan 2000 g pohon $^{-1}$.

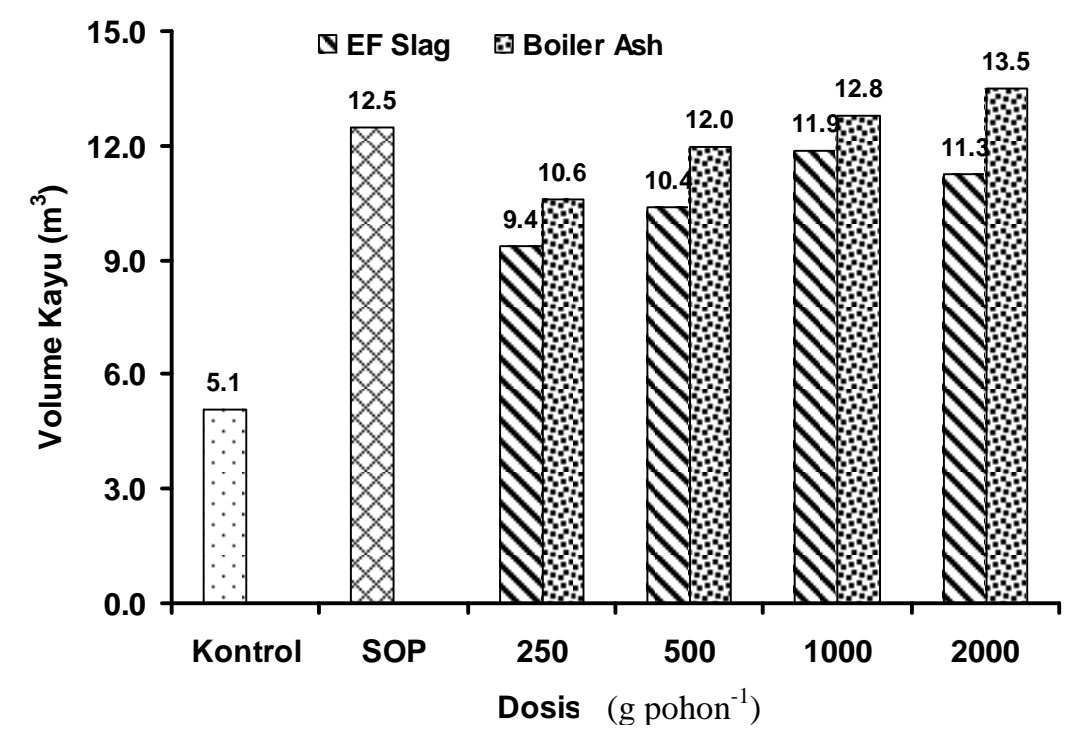

Gambar 4. Pengaruh EF slag dan Boiler Ash terhadap produksi kayu Acacia cracicarpa pada tanah Gambut

Dari hasil percobaan (Gambar 4) diketahui bahwa pemberian EF slag Indonesia secara nyata meningkatkan pertumbuhan dan produksi kayu Acacia cracicarpa. Pada umur satu tahun, produksi kayu pada perlakuan EF slag Indonesia tidak berbeda nyata dengan perlakuan boiler ash maupun SOP (standard operational procedure). Dari hasil percobaan tersebut diketahui bahwa dosis optimum EF slag untuk tanaman Acacia cracicarpa pada tanah gambut adalah $1000 \mathrm{~g}$ pohon $^{-1}$. 


\section{KESIMPULAN}

Dari hasil-hasil penelitian tersebut di atas dapat disimpulkan bahwa steel slag Indonesia (EF slag) dapat dimanfaatkan di bidang pertanian sebagai: (a) bahan pengapuran, (b) pupuk Si pada tanaman padi sawah, dan (c) bahan pembenah tanah gambut. Sebagai bahan pengapuran, pengaruh steel slag Indonesia terhadap pertumbuhan tanaman cenderung lebih baik daripada kalsit maupun dolomit. Kombinasi steel slag dengan guano fosfat dapat meningkatkan efektivitas guano fosfat sebagai pupuk $\mathrm{P}$ secara langsung. Guano fosfat nyata lebih efektif dikombinasikan dengan steel slag daripada dikombinasikan dengan dolomit atau kalsit. Sebagai pupuk Si untuk tanaman padi sawah, steel slag Indonesia dapat meningkatkan pertumbuhan dan produksi padi sawah pada tanah mineral berkadar Si rendah maupun tanah gambut. Pengaruh steel slag pada tanah gambut jauh lebih baik dibanding pada tanah mineral. Sebagai bahan pembenah tanah gambut, steel slag Indonesia dapat meningkatkan pertumbuhan dan produksi kayu Acacia cracicarpa yang ditanam pada tanah gambut.

\section{DAFTAR PUSTAKA}

Anonymous. 1994. Profile in Steel. Mizushima Works, Kawasaki Steel Cooperation, Kurashiki.

Anonymous. 1996. Properties and Effective Use of Steel Slag. Nippon Slag Association, Tokyo.

Ayres, A. S. 1966. Calcium silicate slag as growth stimulant for sugarcane on low silicon soils. Soil Sci., 101:216-227.

Carter, O. R., B. L. Collier, and F. L. Davis. 1951. Blast furnace slags as agricultural liming materials. $J$. Agron., 43:430-433.

Crane, F. H. 1930. A comparison of some effects of blast furnace slag and limestone on an acid soil. J. Am. Soc. Agron., 22:968-973.

De Datta, S. K. 1981. Principles and Practices of Rice Production. John Wiley \& Sons, New York.

Fox, R. L., J. A. Silva, O. R. Younge, D. L. Plucknet, and G. D. Sherman. 1967. Soil and plant silicate response by sugarcane. Soil Sci. Soc. Am. Proc., 31:775-779.

Ma, J. F. and E. Takahashi. 2002. Soil, Fertilizer, and Plant Silicon Research in Japan. Elsevier, Amsterdam.

Naftel, J. A. 1937. Soil liming investigations V: The relation of boron deficiency to over-liming injury. $J$. Am. Soc. Agron., 29:761-771.
Nishiwaki, M. 1986. Tekko. (3) Seiko (kangokintetsu). In Sekkaiseki no Youto to Tokusei. Sekkaiseki Kogyou Kyokai, Tokyo. P. 184-192.

Ota, M., H. Kobayashi, and Y. Kawaguchi. 1955. The effect of slag on paddy rice. Soil and Plant Food, $1: 45-46$.

Suwarno. 1999. Utilization of steel slag as liming material for acid tropical soils. In Proceedings of International Seminar on Toward Sustainable Agriculture in Humid Tropics Facing $21^{\text {st }}$ Century, University of Lampung, Bandar Lampung. P. 293305 .

Suwarno. 2002. Utilization of steel slag in wetland rice cultivation on peat soil. In Proceedings of the International Symposium on Land Management and Biodiversity in South East Asia, Bali. P. 211-215.

Suwarno, A. Rachim, K. Idris, R. Situmorang, dan H. B. Pulunggono. 2003. Penggunaan Kombinasi Guano Fosfat - Terak Baja pada Tanah Tropika Masam dalam Rangka Pengembangan Pupuk Fosfat yang lebih Murahuntuk Tanaman Pangan. Laporan Akhir Project Grant QUE 200/2001.

Suwarno and I. Goto. 1997a. Application of Indonesian electric furnace slag as acid soil amendment. In Proceedings of International Seminar on Development of Agribusiness and Its Impact on Agricultural Production in South East Asia (DABIA). Nodai Center for International Program, Tokyo University of Agriculture, Tokyo. P. 395402 .

Suwarno and I. Goto. 1997b. Mineralogical and chemical properties of Indonesian electric furnace slag and its apliication effect as soil amendment. J. Agric. Sci. Tokyo Univ. Agric., 42:151-162.

Suwarno and I. Goto. 1997c. Effects of Indonesian electric furnace slag on rice yield and chemical properties of soils. In T Ando et al. (Eds). Plant Nutrition - for Sustainable Agriculture and Environment. Kluwer Academic Publisher, Tokyo. P. 803-804.

Umegaki, K. 1986. Tekko. (1) gaisetsu. In Sekkaiseki no Youto to Tokusei. Sekkaiseki Kogyou Kyokai, Tokyo. P. 175-179.

Washimi, K. 1986. Tekko. (5) Suragu. In Sekkaiseki no Youto to Tokusei. Sekkaiseki Kogyou Kyokai, Tokyo. P. 200-2005. 